
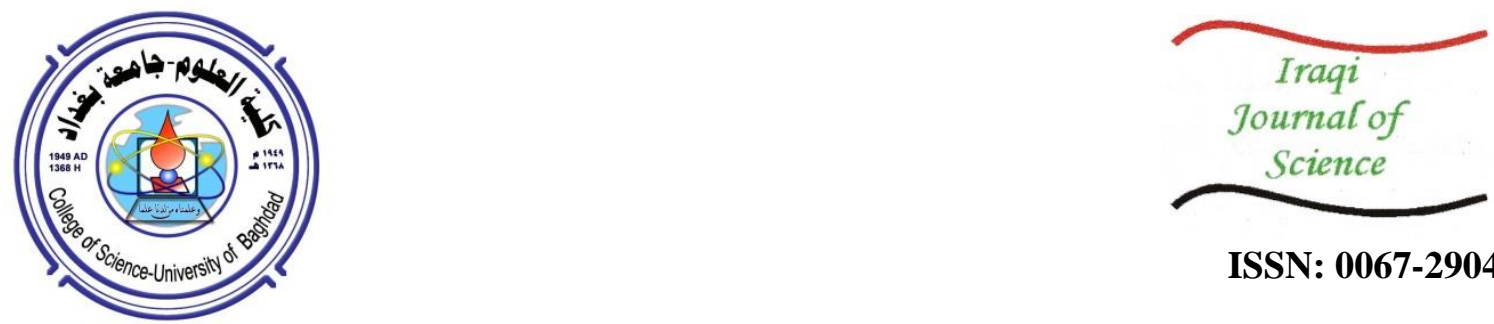

ISSN: 0067-2904

\title{
Assessment of Dibdibba Groundwater Quality Using the Multivariate Statistical Technique in Zuber area South of Iraq
}

\author{
Tariq Abed Hussain ${ }^{1}$, Inass Abdalrazaq Almallah ${ }^{2}$, Wasan S. Al-Qurnawi ${ }^{* 2}$ \\ ${ }^{1}$ Civil Engineering Department-University of Technology-Baghdad \\ ${ }^{2}$ Geology Department-College of Science-University of Basrah
}

Received: 15/5/2021 Accepted: 19/7/2021

\begin{abstract}
Thirty-three samples of groundwater were taken from Dibdibba unconfined aquifer in the Zuber area southwestern parts of Basrah governorate south of Iraq to assess the groundwater quality. A statistical multivariate analysis was done using cations and anions, $\mathrm{pH}$, total dissolved solids (TDS), and electrical conductivity (EC) that were measured for drinking, livestock, and construction purposes. Residual sodium bicarbonate (RSBC), Magnesium Ratio (MR), and Permeability index (PI) were used to evaluate the suitability of the present samples for irrigation activity. The quality of groundwater in the study area is unsuitable for drinking water, industrial and building uses. But it is suitable for livestock uses, According to Residual Sodium Carbonate and Magnesium Ratio the groundwater in the study area are suitable for irrigation purposes, but unsuitable for Permeability index. Multivariate analysis results indicate the high positive correlation between Ec and TDS with other constituents, two significant clusters I and II are obtained with significant Ec and TDS responsible for playing the most effective in classifying the present samples. $71.85 \%$ and $12.21 \%$ of the present of the total variance of the groundwater samples were explained by Factor analyses, Factor I indicated increasing $\mathrm{Cl}^{-}, \mathrm{Mg}^{+2}, \mathrm{Na}^{+}$, and $\mathrm{Ca}^{+2}$ with the highest weight and Factor II show lower weight average of $\mathrm{K}^{+}$concentration only. The results confirm the dissolution of sulfate salts and evaporate minerals, in addition to high agricultural lands and farm activities, besides the wastes from chemical construction industries.
\end{abstract}

Keywords: Groundwater quality, Multivariate analyses, Dibdibba formation, Zuber, Iraq.

\section{التقييم النوعي لخزان الدبدة باستخدام التقانات الاحصائية المتعددة المتغيرات في منطقة الزبير جنوب}

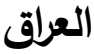

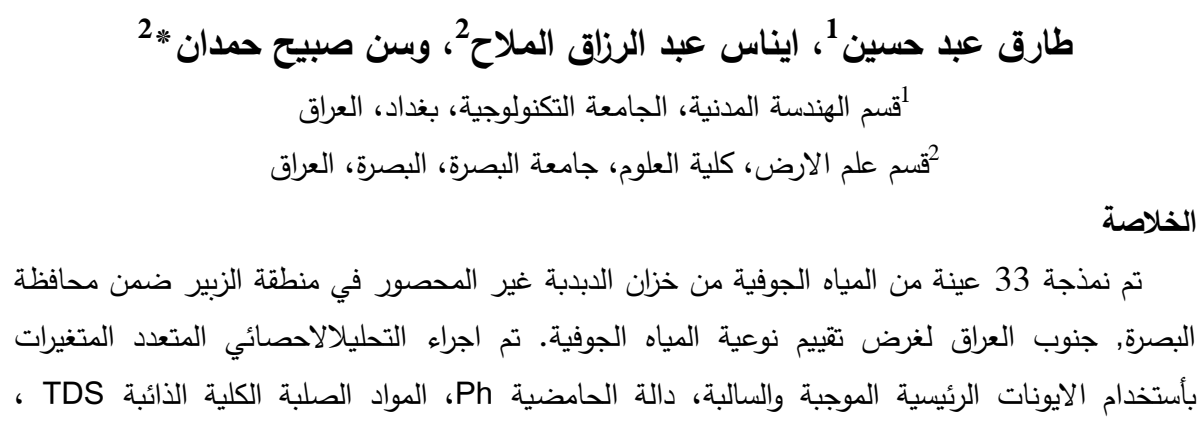

*Email: wasan.hamdan@uobasrah.edu.iq 


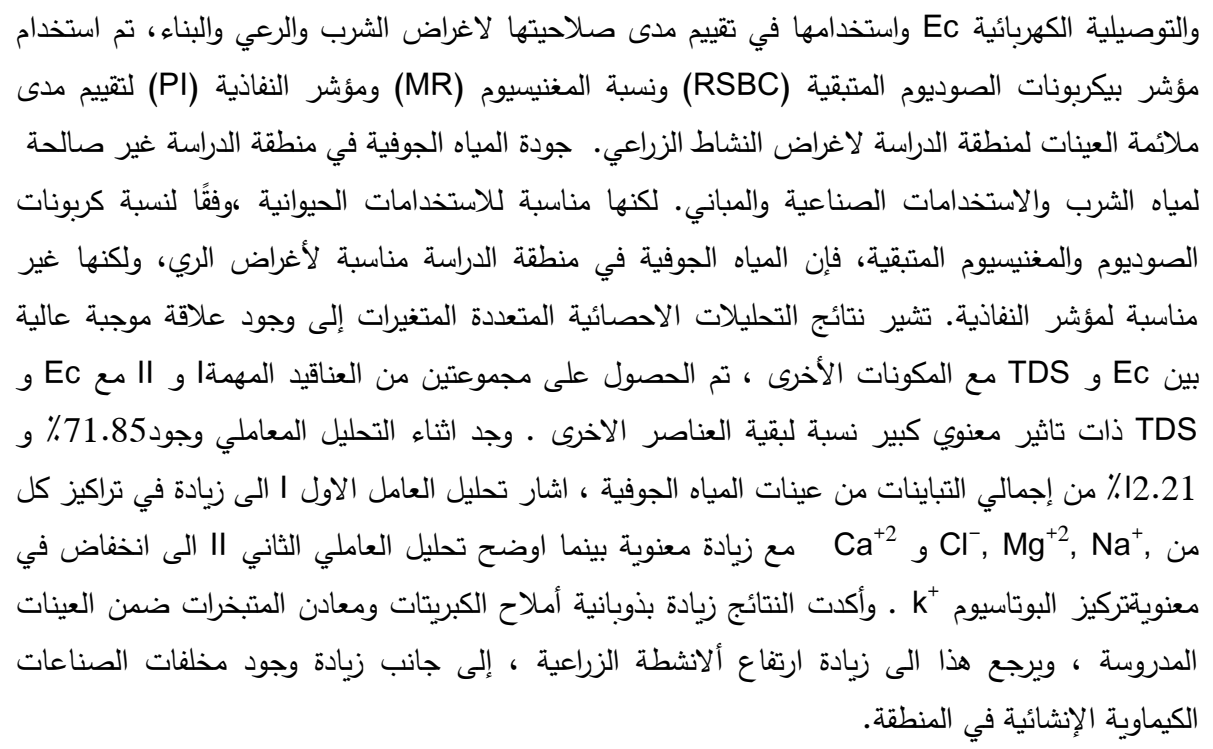

\section{1- Introduction:}

In the southwest of Iraq, Zuber-Safwan is located in the province of Basra in Zuber-Safwan between longitudes $\left(47^{\circ} 30^{\prime} 0^{\prime \prime}-47^{\circ} 50^{\prime} 0^{\prime \prime}\right)$ Easting and latitudes $\left(30^{\circ} 12^{\prime} 0^{\prime \prime}-30^{\circ} 25^{\prime} 0^{\prime \prime}\right)$ Northing, (Figure-1). In this regian there are some of trough valleys, some of which are occupied by drainage, which are common in the southern and western parts of the study area. In the rainy season, the valleys are going to be filled with water and are regarded as a recharge system for the main aquifer [1].

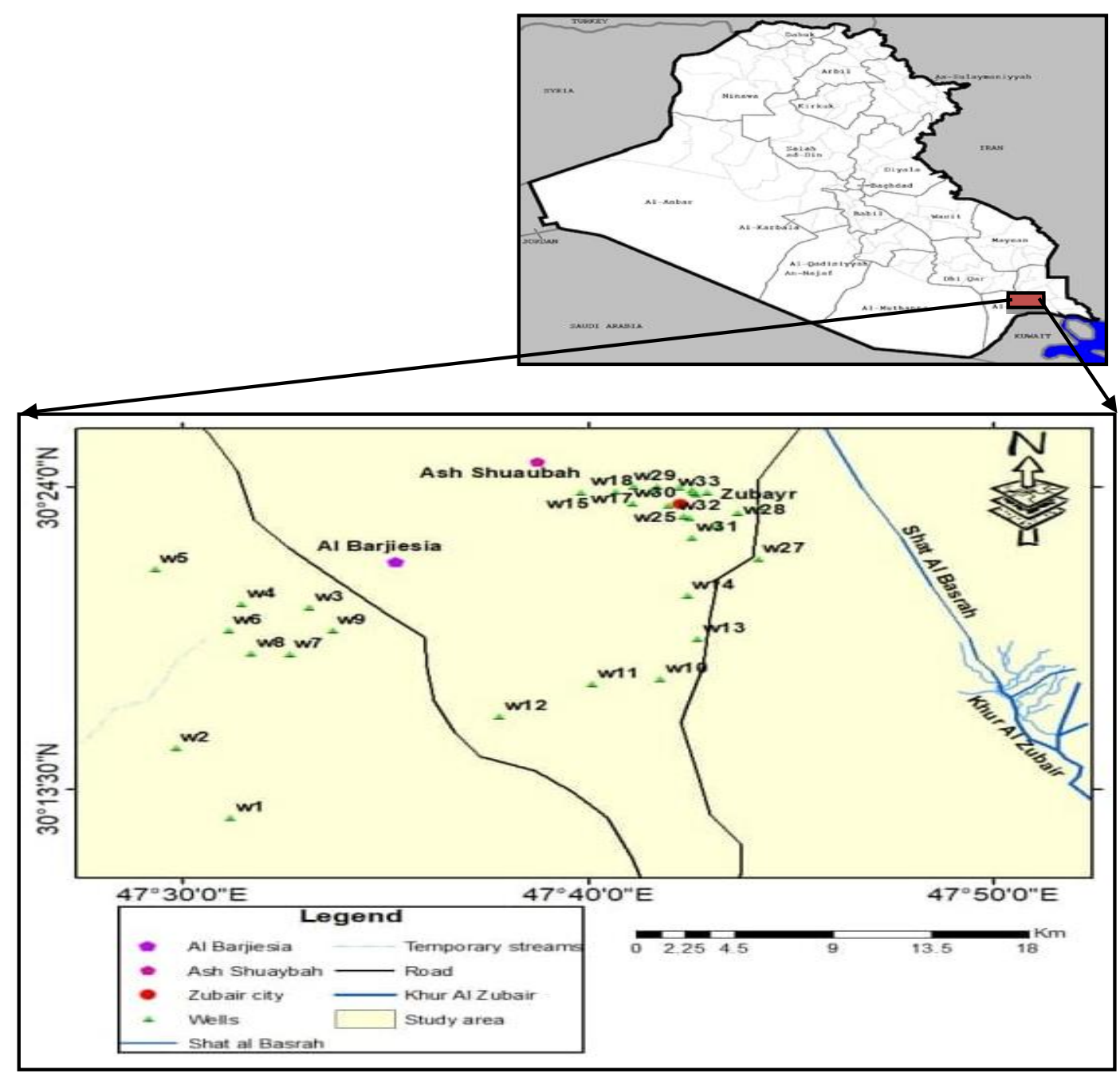

Figure 1- The location map of the study area 
Geologically the area is covered by the formation of Dibdibba containing sandy gravel soil. In Dibdibba plain there are numerous geomorphological features in the area, Sand dunes, and shallow wadies including Jabal Sanam hill [2]. In the Mesopotamia area and Zuber area is located within Sagged Basin according to the tectonic divisions of Iraq of the Arabian plate [3].The Mesopotamian Valley is divided into three sub-regions [4] which are Euphrates Subzone, Tigris Subzone and Zuber Subzone. The study area is located within Zuber Subzone.

Dibdibba is considered to be the most important aquifer of the study region in which both the top of the aquifer is unconfined and semi-confined to confined, separated in the deepest layer of the aquifer by a hard clay layer of two to four meters thick. [2].The flow area pattern is distinguished by a path from the west and southwest of the area to the east and northeast towards the Khor al-Zuber drainage area, as well as the Channel of Shatt AL-Basrah, depending on corrected static water levels. (Figure3).The structural and geological status regulates the flow movement of the groundwater. There are a large number of studies that including the study of Dibdibba aquifer like: [5], who carried out a study on the groundwater quality and hydro-geochemical processes of the shallow Dibdibba aquifer in Basra Governorate, southern Iraq, and concluded that all groundwater samples are not appropriate for human drinking use and for irrigation, as well as noticing a deterioration in the quality of groundwater due to the drilling of a large number of wells In the region, [6] In addition, a study titled Hydrochemical Assessment of Groundwater of Dibdibba Aquifer in Al-Zuber Area, Basra, South of Iraq, and its Suitability Irrigation Purposes was carried out. And concluded that groundwater belongs to $\mathrm{Na}, \mathrm{Mg}$, and Ca-Chloride types. The predominance of calcium is obtained mainly by dissolving gypsum. [7] Study type quality of groundwater in elected wells in the Zuber area and the water is classified as having a high rate of minerals. They also concluded that the studied groundwater wells are not suitable for drinking by humans. The research proposed to re-evaluate the under groundwater in the Al-Zuber area as well as to study the multivariate analyzes of the studied samples in the area in addition to studying the validity of groundwater for different uses.

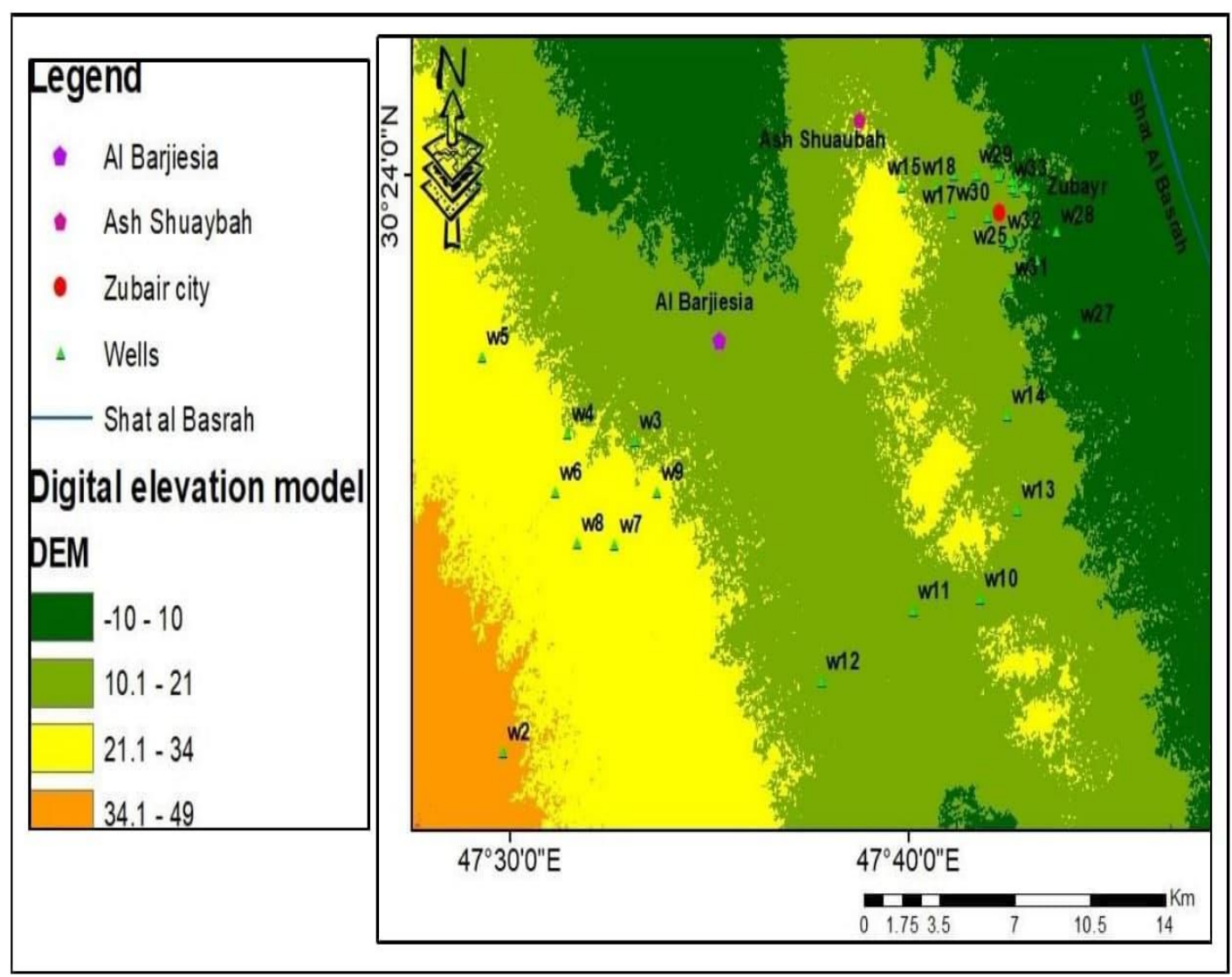

Figure 2- Surface elevation map Digital Elevation Model (DEM) of the study area. 


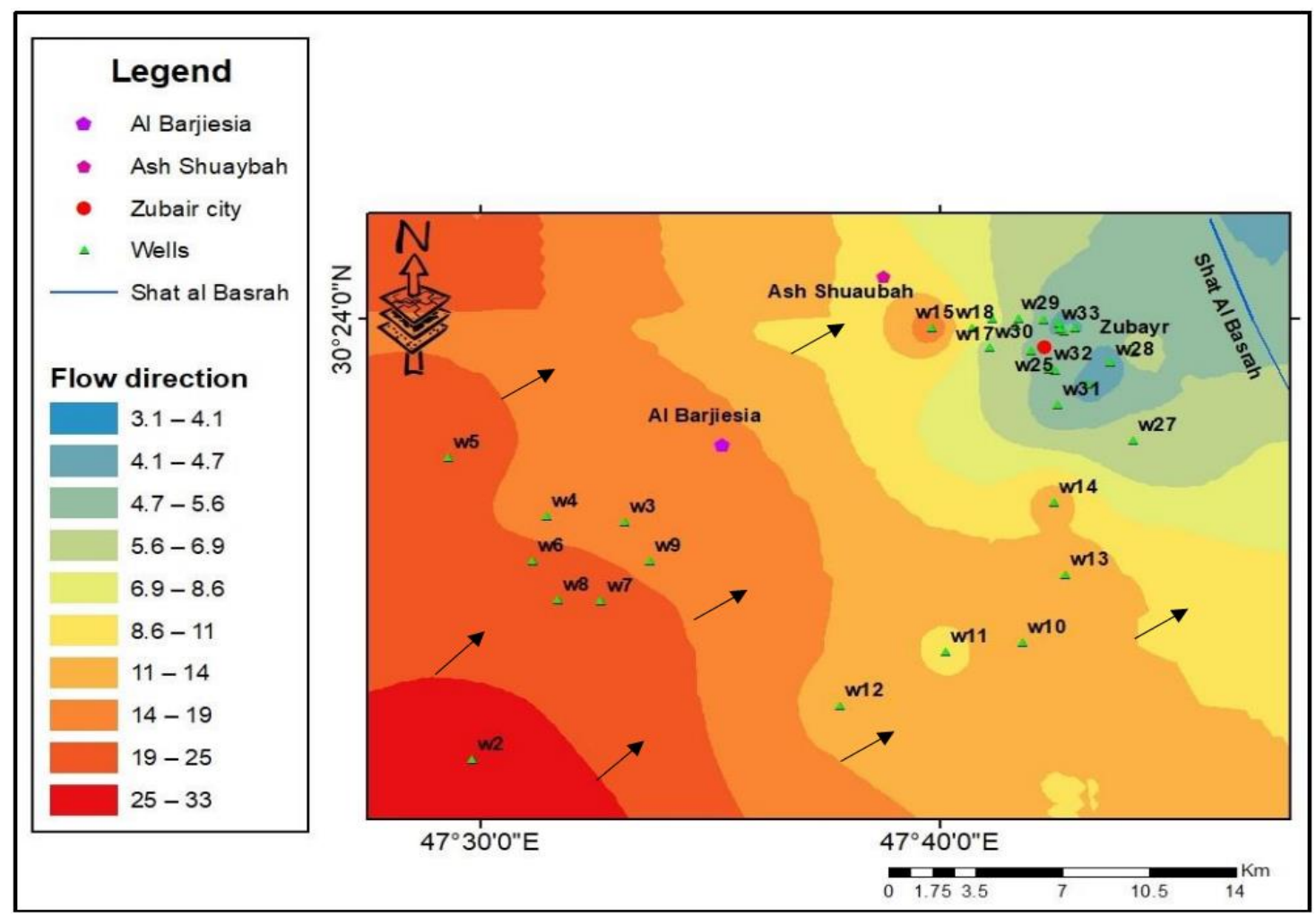

Figure 3- The groundwater flow map of the study area.

\section{Materials and Methods}

The physical and chemical parameters of Thirty-three groundwater wells in the Zuber area (Figure-1), were obtained from the General Commission for Groundwater in Baghdad, The analyzes were conducted during October 2018 to assess the quality of groundwater for the Dibdibba Shallow aquifer in Al-Zuber area in Basra Governorate through studying the hydrochemical characteristics of groundwater and evaluation its suitability for different uses. The Groundwater wells characteristics and cations $\left(\mathrm{K}^{+}, \mathrm{Na}^{+}, \mathrm{Mg}^{+2}, \mathrm{Ca}^{+2}\right)$, anions $\left(\mathrm{Cl}^{-}, \mathrm{SO}_{4}^{-2}, \mathrm{HCO}_{3}{ }^{-}, \mathrm{CO}_{3}{ }^{-2}, \mathrm{NO}_{3}{ }^{-}\right), \mathrm{pH}, \mathrm{EC}$, and TDS as shown in Table-1. Residual sodium bicarbonate (RSBC), permeability index (PI), and magnesium (MR) were calculated according to reference research. Descriptive and multivariate analyses were evaluated using statistical SPSS program software version 22 to estimate the most hydrochemical parameters responsible for groundwater quality of the study area.

The accuracy or systematic error is an error due to a mistake in the method of work or interference during the analysis [8], when the relative difference is less than $5 \%$ the results will be acceptable and between $5-10 \%$, the results will be used with caution, but in case of being greater than $10 \%$ hydrochemical interpretations are not reliable and Concentrations are calculated in epm units. The accuracy analysis of groundwater samples results show within the allowable limits, then it can be relied upon in hydrochemical interpretations (Tables- 1 and 2).

Table 1- Physical and chemical parameters in ppm units of groundwater wells

\begin{tabular}{|c|c|c|c|c|c|c|c|c|c|c|c|c|c|}
\hline$\dot{\mathbf{z}}$ & 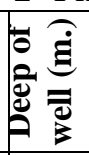 & 굴 & 도일 & $\tilde{1}$ & 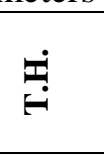 & $\checkmark$ & $\stackrel{\pi}{Z}$ & $\sum^{\infty}$ & ש & $\bar{\tau}$ & ర్ & 仓ొ & ô \\
\hline w1 & 40 & 7.16 & 9090 & $\begin{array}{c}635 \\
2 \\
\end{array}$ & $\begin{array}{c}1817 . . \\
2 \\
\end{array}$ & 13.3 & 725 & 192 & 412 & 945 & 1574 & 538 & 2 \\
\hline W2 & 40 & 7.14 & 8620 & $\begin{array}{c}602 \\
9 \\
\end{array}$ & $\begin{array}{c}2360 . \\
2 \\
\end{array}$ & 16 & 735 & 222 & 580 & 1086 & 1795 & 695 & 2 \\
\hline W3 & 24 & 7.12 & 9580 & $\begin{array}{c}667 \\
1 \\
\end{array}$ & 1788 & 19 & 742 & 180 & 420 & 937 & 1608 & 525 & 4 \\
\hline W4 & 30 & 7.28 & 6920 & $\begin{array}{c}487 \\
6 \\
\end{array}$ & $\begin{array}{c}1700 . \\
8\end{array}$ & 70 & 792 & 188 & 372 & 845 & 1699 & 672 & 3 \\
\hline
\end{tabular}




\begin{tabular}{|c|c|c|c|c|c|c|c|c|c|c|c|c|c|}
\hline W5 & 30 & 7.31 & 6330 & $\begin{array}{c}446 \\
0\end{array}$ & 1046 & 40 & 580 & 140 & 340 & 680 & 1483 & 403 & 3 \\
\hline W6 & 30 & 7.23 & 8160 & $\begin{array}{c}575 \\
1\end{array}$ & $\begin{array}{c}1977 . \\
8\end{array}$ & 11.7 & $\begin{array}{c}694 . \\
7\end{array}$ & $\begin{array}{c}204 . \\
1\end{array}$ & 456.6 & 962 & 1584 & 555 & 0.2 \\
\hline W7 & 30 & 7.62 & 9730 & $\begin{array}{c}676 \\
8\end{array}$ & $\begin{array}{c}1914 . \\
3\end{array}$ & 23.4 & 762 & 198 & 441 & 994 & $\begin{array}{c}1684 . \\
8\end{array}$ & 610 & 4 \\
\hline W8 & 30 & 7.11 & 10840 & $\begin{array}{c}753 \\
9\end{array}$ & 1691 & 39 & 900 & 240 & 542 & $\begin{array}{c}1242 \\
.5\end{array}$ & 1920 & 793 & 5.5 \\
\hline W9 & 24 & 7.25 & 7950 & $\begin{array}{c}560 \\
8\end{array}$ & $\begin{array}{c}1828 . \\
8\end{array}$ & 11.9 & 719 & 193 & 415 & 938 & 1556 & 535 & 3.1 \\
\hline $\begin{array}{c}\mathrm{W} 1 \\
0\end{array}$ & 15 & 7.39 & 8120 & $\begin{array}{c}572 \\
5\end{array}$ & $\begin{array}{c}1326 . \\
1\end{array}$ & 12 & 723 & 199 & 419 & 945 & 1560 & 541 & 2.9 \\
\hline $\begin{array}{c}\mathrm{W} 1 \\
1\end{array}$ & 12 & 7.09 & 14190 & $\begin{array}{c}996 \\
0\end{array}$ & $\begin{array}{c}2526 . \\
22\end{array}$ & 74 & $\begin{array}{c}1384 \\
.8\end{array}$ & $\begin{array}{c}372 . \\
3\end{array}$ & 802 & 2201 & 2256 & 1342 & 9.1 \\
\hline $\begin{array}{c}\text { W1 } \\
2\end{array}$ & 16 & 7.7 & 10430 & $\begin{array}{c}726 \\
9 \\
\end{array}$ & $\begin{array}{c}1839 . \\
58\end{array}$ & 74.1 & $\begin{array}{c}1084 \\
.7\end{array}$ & $\begin{array}{c}312 . \\
2\end{array}$ & 561 & 1526 & $\begin{array}{c}2068 . \\
8\end{array}$ & 915 & 6.2 \\
\hline $\begin{array}{c}\text { W1 } \\
3\end{array}$ & 16 & 7.19 & 7510 & $\begin{array}{c}531 \\
9\end{array}$ & 1177 & 11 & 628 & 180 & 370 & 740 & 1512 & 514 & 2.1 \\
\hline $\begin{array}{c}\text { W1 } \\
4\end{array}$ & 17 & 7.23 & 7900 & $\begin{array}{c}557 \\
5\end{array}$ & 1291 & 13 & 720 & 190 & 410 & 941 & 1560 & 537 & 2 \\
\hline $\begin{array}{c}\mathrm{W} 1 \\
5\end{array}$ & 27 & 7.2 & 13300 & $\begin{array}{c}986 \\
0\end{array}$ & $\begin{array}{c}2031 . \\
9\end{array}$ & 77 & 1150 & 346 & 619 & 1595 & 2254 & 1090 & 11 \\
\hline $\begin{array}{c}\text { W1 } \\
6\end{array}$ & 25 & 7.67 & 3580 & $\begin{array}{c}264 \\
0\end{array}$ & $\begin{array}{c}1223 . \\
2\end{array}$ & 81 & 411 & 127 & 281 & 546 & 997 & 454 & 7 \\
\hline $\begin{array}{c}\text { W1 } \\
7\end{array}$ & 16 & 7.51 & 4890 & $\begin{array}{c}358 \\
0\end{array}$ & $\begin{array}{c}1477 . \\
8\end{array}$ & 116 & 534 & 158 & 332 & 715 & 1300 & 508 & 4 \\
\hline $\begin{array}{c}\text { W1 } \\
8\end{array}$ & 30 & 7.17 & 6240 & $\begin{array}{c}444 \\
5\end{array}$ & $\begin{array}{c}1604 . \\
8\end{array}$ & 99 & 608 & 178 & 350 & 700 & 1830 & 509 & 2 \\
\hline $\begin{array}{c}\text { W1 } \\
9\end{array}$ & 17 & 7.62 & 5003 & $\begin{array}{c}389 \\
0\end{array}$ & $\begin{array}{c}1379 . \\
3\end{array}$ & 97 & 545 & 148 & 309 & 668 & 1297 & 488 & 2 \\
\hline $\begin{array}{c}\text { W2 } \\
0\end{array}$ & 24 & 7.31 & 6300 & $\begin{array}{c}448 \\
2 \\
\end{array}$ & 1481 & 99 & 568 & 160 & 330 & 681 & 1413 & 492 & 2.5 \\
\hline $\begin{array}{c}\text { W2 } \\
1\end{array}$ & 17 & 7.18 & 10310 & $\begin{array}{c}780 \\
0\end{array}$ & $\begin{array}{c}2345 . \\
6\end{array}$ & 39 & 906 & 241 & 543 & 1242 & 1912 & 791 & 5 \\
\hline $\begin{array}{c}\text { W2 } \\
2\end{array}$ & 18 & 7.11 & 13930 & $\begin{array}{c}104 \\
15\end{array}$ & $\begin{array}{c}2548 . \\
3\end{array}$ & 72 & 1380 & 372 & 811 & 2209 & 3260 & 1340 & 10 \\
\hline $\begin{array}{c}\text { W2 } \\
3\end{array}$ & 22 & 7.14 & 5220 & $\begin{array}{c}380 \\
0\end{array}$ & $\begin{array}{c}1083 . \\
8\end{array}$ & 18 & 615 & 167 & 340 & 645 & 1445 & 487 & 2 \\
\hline $\begin{array}{c}\text { W2 } \\
4 \\
\end{array}$ & 24 & 7.51 & 8730 & $\begin{array}{c}643 \\
7 \\
\end{array}$ & $\begin{array}{c}1547 . \\
4\end{array}$ & 120 & 586 & 164 & 350 & 791 & 1367 & 310 & 2.3 \\
\hline $\begin{array}{c}\text { W2 } \\
5\end{array}$ & 24 & 7.12 & 6230 & $\begin{array}{c}433 \\
8\end{array}$ & 1572 & 50 & 600 & 170 & 350 & 681 & 1520 & 512 & 2 \\
\hline $\begin{array}{c}\text { W2 } \\
6\end{array}$ & 25 & 7.14 & 7005 & $\begin{array}{c}493 \\
3\end{array}$ & $\begin{array}{c}1551 . \\
3\end{array}$ & 91 & 570 & 168 & 345 & 680 & 1519 & 479 & 2.5 \\
\hline $\begin{array}{c}\text { W2 } \\
7\end{array}$ & 18 & 7.11 & 5810 & $\begin{array}{c}396 \\
0\end{array}$ & 973 & 93 & 543 & 145 & 308 & 665 & 1292 & 488 & 3 \\
\hline $\begin{array}{c}\text { W2 } \\
8\end{array}$ & 16 & 7.43 & 5720 & $\begin{array}{c}389 \\
0\end{array}$ & $\begin{array}{c}1526 . \\
5\end{array}$ & 18 & 614 & 165 & 340 & 675 & 1445 & 481 & 2.5 \\
\hline $\begin{array}{c}\text { W2 } \\
9\end{array}$ & 24 & 7.31 & 5310 & $\begin{array}{c}374 \\
8\end{array}$ & $\begin{array}{c}1532 . \\
2\end{array}$ & 17 & 615 & 167 & 339 & 673 & 1445 & 479 & 2.5 \\
\hline $\begin{array}{c}\text { W3 } \\
0\end{array}$ & 24 & 7.23 & 4160 & $\begin{array}{c}301 \\
8\end{array}$ & $\begin{array}{c}1427 . \\
5\end{array}$ & 114 & 530 & 150 & 325 & 710 & 1213 & 806 & 3 \\
\hline $\begin{array}{c}\text { W3 } \\
1\end{array}$ & 18 & 7.21 & 7900 & $\begin{array}{c}550 \\
6\end{array}$ & $\begin{array}{c}1292 . \\
1\end{array}$ & 13 & 721 & 189 & 411 & 939 & 1549 & 540 & 3 \\
\hline $\begin{array}{c}\text { W3 } \\
2\end{array}$ & 24 & 7.11 & 4430 & $\begin{array}{c}328 \\
5\end{array}$ & $\begin{array}{c}1358 . \\
1\end{array}$ & 95 & 509 & 141 & 312 & 681 & 1182 & 481 & 2 \\
\hline $\begin{array}{c}\text { W3 } \\
3\end{array}$ & 24 & 7.14 & 3970 & $\begin{array}{c}289 \\
0\end{array}$ & $\begin{array}{c}1175 . \\
7\end{array}$ & 80 & 416 & 127 & 262 & 540 & 990 & 450 & 9 \\
\hline
\end{tabular}


Table 2- concentrations of major cations and anions for the study area in epm units

\begin{tabular}{|c|c|c|c|c|c|c|c|c|}
\hline Well NO. & $\mathbf{K}$ & $\mathbf{N a}$ & Mg & $\mathbf{C a}$ & $\mathrm{Cl}$ & SO4 & $\mathrm{HCO3}$ & Accuracy \\
\hline w1 & 0.34 & 31.537 & 15.793 & 20.558 & 26.658 & 32.77 & 8.817 & 0.045 \\
\hline W2 & 0.409 & 31.972 & 18.261 & 28.942 & 30.636 & 37.371 & 11.391 & 0.0868 \\
\hline W3 & 0.485 & 32.277 & 14.806 & 20.958 & 26.432 & 33.478 & 8.604 & 0.575 \\
\hline W4 & 1.789 & 34.452 & 15.464 & 18.562 & 23.837 & 35.373 & 11.014 & 0.032 \\
\hline W5 & 1.022 & 25.23 & 11.516 & 16.966 & 19.182 & 30.876 & 6.605 & 1.784 \\
\hline W6 & 0.299 & 30.219 & 16.789 & 22.784 & 27.138 & 32.978 & 9.096 & 0.631 \\
\hline W7 & 0.598 & 33.147 & 16.287 & 22.005 & 28.04 & 35.077 & 9.997 & -0.741 \\
\hline W8 & 0.99 & 39.15 & 19.742 & 27.045 & 35.05 & 39.974 & 12.997 & 0.627 \\
\hline W9 & 0.304 & 31.276 & 15.876 & 20.708 & 26.46 & 32.395 & 8.768 & 0.397 \\
\hline W10 & 0.306 & 31.4505 & 16.369 & 20.908 & 26.658 & 32.479 & 8.866 & 0.582 \\
\hline W11 & 1.892 & 60.2388 & 30.625 & 40.019 & 62.09 & 46.969 & 21.995 & 0.585 \\
\hline W12 & 1.894 & 47.18445 & 25.681 & 27.993 & 43.048 & 43.072 & 14.996 & 7.9 \\
\hline W13 & 0.281 & 27.318 & 14.806 & 18.463 & 20.875 & 31.479 & 8.424 & 0.038 \\
\hline W14 & 0.332 & 31.32 & 15.629 & 20.459 & 26.545 & 32.479 & 8.801 & 0.079 \\
\hline W15 & 1.968 & 50.025 & 28.461 & 30.888 & 44.994 & 46.928 & 17.865 & 0.611 \\
\hline W16 & 2.071 & 17.878 & 10.447 & 14.021 & 15.402 & 20.757 & 7.441 & 0.929 \\
\hline W17 & 2.966 & 23.229 & 12.997 & 16.566 & 20.17 & 27.066 & 8.326 & 0.203 \\
\hline W18 & 2.531 & 26.448 & 14.642 & 17.465 & 19.747 & 38.1 & 8.342 & -4.009 \\
\hline W19 & 2.480 & 23.707 & 12.174 & 15.419 & 18.844 & 27.003 & 7.998 & -0.055 \\
\hline W20 & 2.531 & 24.708 & 13.161 & 16.467 & 19.211 & 29.418 & 8.063 & 0.154 \\
\hline W21 & 0.997 & 39.411 & 19.824 & 27.095 & 35.036 & 39.807 & 12.964 & -0.274 \\
\hline W22 & 1.841 & 60.03 & 30.6 & 40.468 & 62.315 & 67.873 & 21.962 & 6.799 \\
\hline W23 & 0.46 & 26.752 & 13.737 & 16.966 & 18.195 & 30.084 & 7.981 & 1.406 \\
\hline W24 & 3.068 & 25.491 & 13.49 & 17.465 & 22.314 & 28.46 & 5.081 & 3.172 \\
\hline W25 & 1.278 & 26.1 & 13.984 & 17.465 & 19.211 & 31.646 & 8.391 & -0.356 \\
\hline W26 & 2.326 & 24.795 & 13.819 & 17.215 & 19.182 & 31.625 & 7.85 & -0.429 \\
\hline W27 & 2.378 & 23.620 & 11.927 & 15.369 & 18.759 & 26.899 & 7.998 & 0.407 \\
\hline W28 & 0.460 & 26.709 & 13.572 & 16.966 & 19.041 & 30.084 & 7.883 & 0.609 \\
\hline W29 & 0.434 & 26.752 & 13.737 & 16.916 & 18.985 & 30.084 & 7.85 & 0.8008 \\
\hline W30 & 2.914 & 23.055 & 12.339 & 16.217 & 20.029 & 25.254 & 13.21 & -3.51 \\
\hline W31 & 0.332 & 31.363 & 15.547 & 20.508 & 26.489 & 32.25 & 8.85 & 0.059 \\
\hline W32 & 2.429 & 22.141 & 11.598 & 15.568 & 19.211 & 24.609 & 7.883 & 0.063 \\
\hline W33 & 2.045 & 18.096 & 10.447 & 13.073 & 15.233 & 20.611 & 7.375 & 0.508 \\
\hline
\end{tabular}

\section{2- Results and Discussion}

Table-3 show the descriptive statistics results of the present groundwater samples

\section{2-1 Physical Properties}

In natural waters, the color comes from many reasons such as organic matter, dissolved components, and hemic compounds, which will be enhanced at high water temperature [9]. And from iron, decay organism, planktons, manganese oxides, and industrial wastes [8].The present study results show that all groundwater samples are colorless and odorless, while it has salty taste in some of the groundwater samples due to the increase in TDS values, which causes the salty taste.

Table 3-The descriptive statistics of the physical and chemical properties of groundwater of the study area

\begin{tabular}{|c|c|c|c|c|}
\hline Parameter & Minimum & Maximum & Mean & Std. Deviation \\
\hline $\mathrm{pH}$ & 7 & 8 & 7.27 & 0.181 \\
\hline $\mathrm{EC}(\mathrm{ms} / \mathrm{cm})$ & 3580 & 14190 & 7679.03 & 2774.448 \\
\hline $\mathrm{TDS}(\mathrm{ppm})$ & 2640 & 10415 & 5479.36 & 2009.351 \\
\hline $\mathrm{K}^{+}(\mathrm{ppm})$ & 11 & 120 & 55.07 & 37.903 \\
\hline
\end{tabular}




\begin{tabular}{|c|c|c|c|c|}
\hline $\mathrm{Na}^{+}(\mathrm{ppm})$ & 411 & 1385 & 715.49 & 236.316 \\
\hline $\mathrm{Mg}^{+2}(\mathrm{ppm})$ & 127 & 372 & 196.78 & 64.792 \\
\hline $\mathrm{Ca}^{+2}(\mathrm{ppm})$ & 262 & 811 & 418.11 & 133.745 \\
\hline $\mathrm{Cl}^{-}(\mathrm{ppm})$ & 540 & 2209 & 939.95 & 412.408 \\
\hline $\mathrm{SO}_{4}^{-2}(\mathrm{ppm})$ & 990 & 3260 & 1608.81 & 421.302 \\
\hline $\mathrm{HCO}_{3}{ }^{-2}(\mathrm{ppm})$ & 310 & 1342 & 616.97 & 243.090 \\
\hline $\mathrm{NO}_{3}^{-2}(\mathrm{ppm})$ & .20 & 11.00 & 3.8303 & 2.62863 \\
\hline RSBC & -18.506 & -3.007 & -10.75151 & 3.475819 \\
\hline MR & 38.687 & 47.956 & 43.65667 & 1.767339 \\
\hline PI & 0.004 & 0.006 & 0.00503 & 0.000166 \\
\hline
\end{tabular}

The temperature has an impact on the acceptability of chemical contaminants and inorganic constituents that may affect groundwater characteristics, where the high water temperature tends to odor, taste, color and corrosion problems [9]. In the study area, groundwater temperature is ranged (21.8-23) with an average $22 \mathrm{C}^{\circ}$

Hydrogen Number $(\mathrm{pH})$ measurement is among the most important and widely used water chemistry tests, and it plays an important role in the chemical and biological properties of water. [10]The $\mathrm{pH}$ values in the groundwater samples rang between (7.09-7.7) with an average (7.27). This indicates that most well water is weakly alkaline.

TDS (Total Dissolved Solids) in a water sample denotes all dissolved, ionized or non-ionized solids in solution. When calculating TDS suspended materials, colloids, or dissolved gases are not taken into account [11] .TDS values in the groundwater samples range between (3800-10415) ppm with an average (5479.36) ppm. According to [12]and [13]the water samples are considered to be Slightlybrackish water.

The Electrical Conductivity (EC) value of groundwater samples ranged between $(3580-14190)(\mu \mathrm{s} / \mathrm{cm})$ with an average of $7679.03(\mu \mathrm{s} / \mathrm{cm})$. According to [14], the groundwater samples in the study are classified as excessively mineralized water. Figures- (4 and 5) show the distribution of TDS and Ec within the study area, with the greatest concentrations concentrated in the northern part of the study area due to increased irrigation purposes in addition to municipal activity in these areas

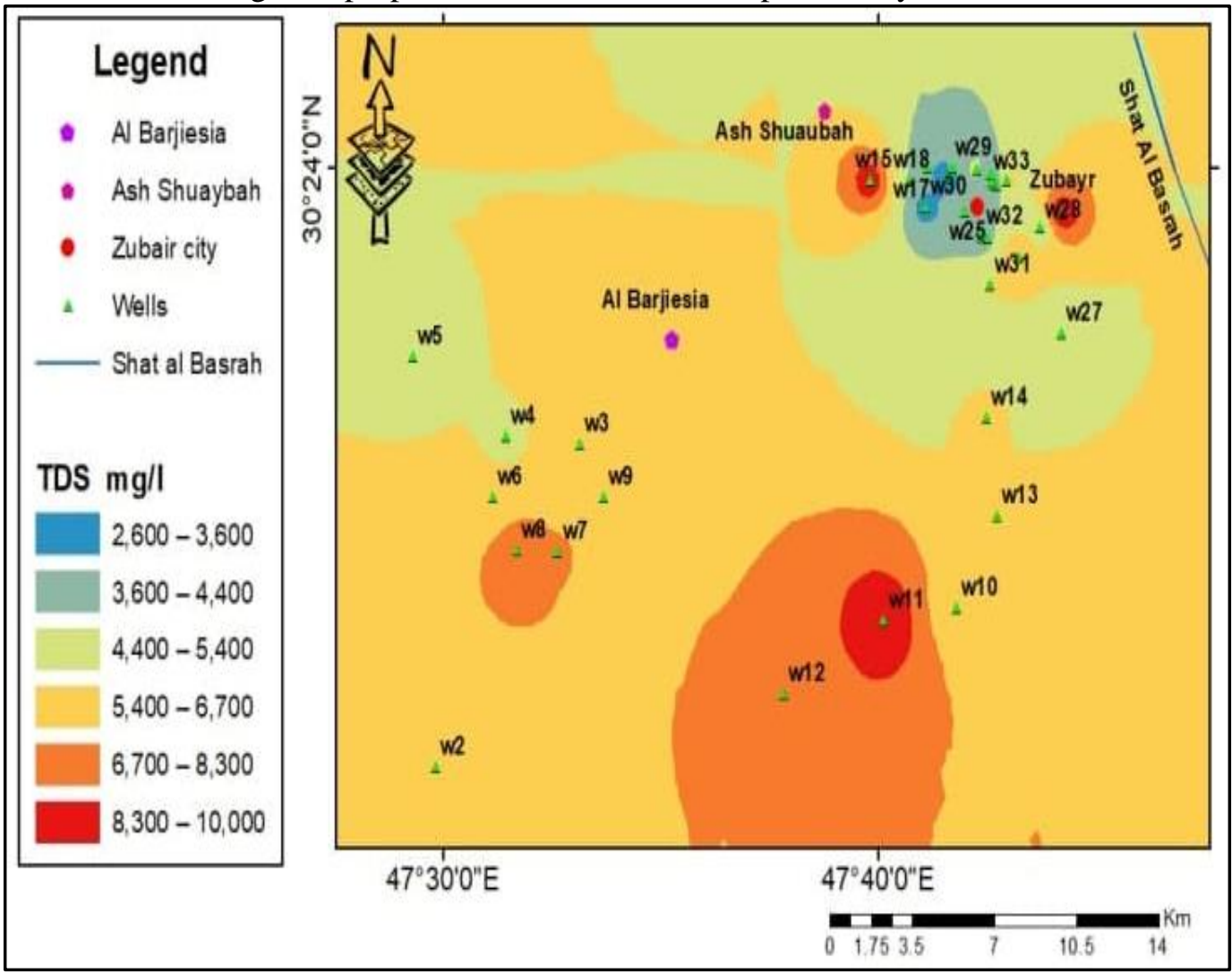

Figure 4- Total dissolved solids (ppm) distribution in the study area. 


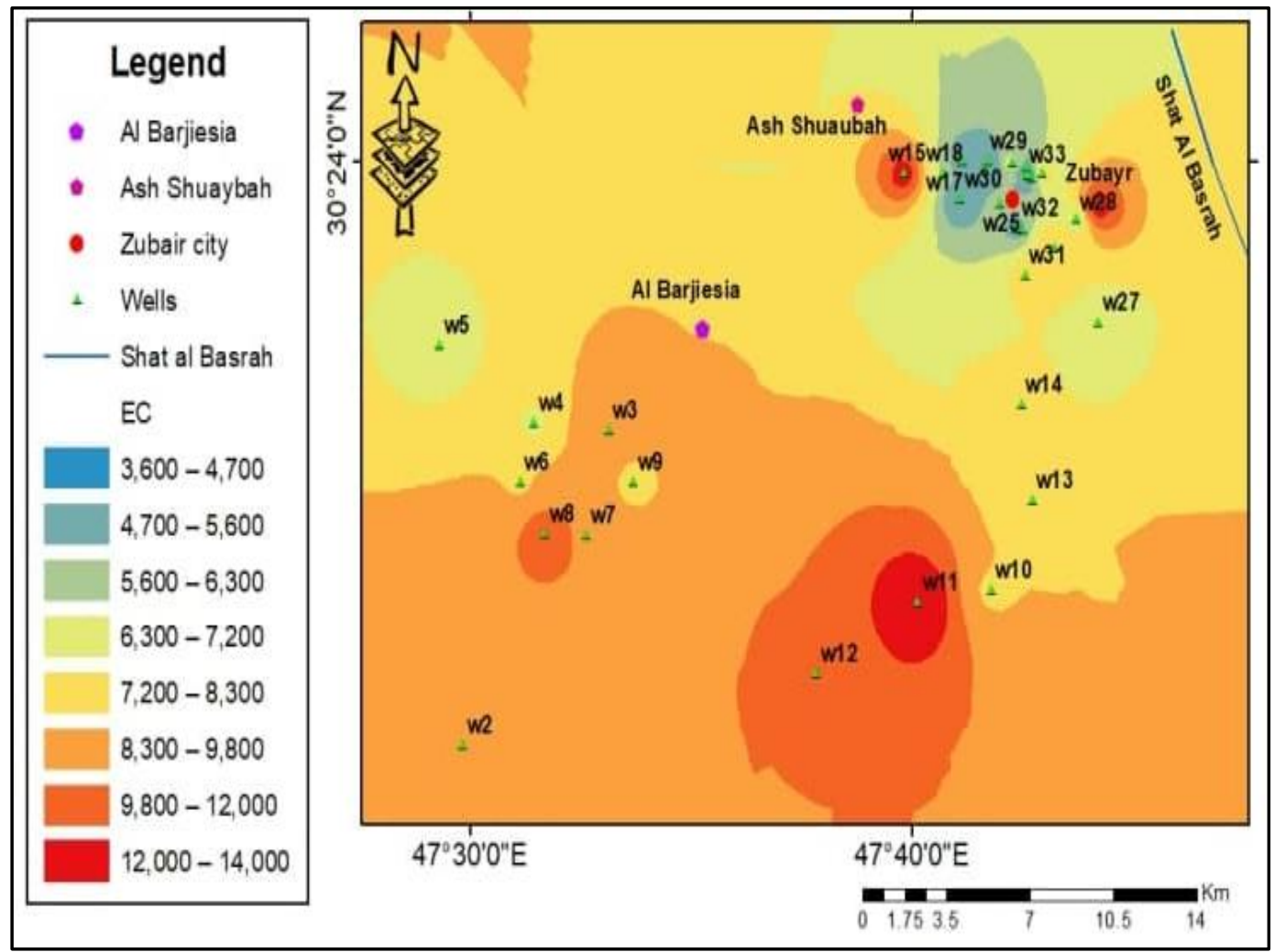

Figure 5- Electricity concentration $(\mu \mathrm{s} / \mathrm{cm})$ distribution in the study area.

\section{2-2: Chemical analysis:}

Calcium is one of the alkaline elements that have a major presence in the earth's crust. It is formed as a natural byproduct of the dissolution of sedimentary rocks such as limestone, dolomite, and gypsum [15]. General, groundwater chemistry reflects the aquifer lithology. The high concentration of calcium in the study area comes from dissolved carbonate rocks that are found in Dibdibba Formation. The concentration of calcium $\left(\mathrm{Ca}^{+2}\right)$ in the groundwater samples ranges between (262-811) ppm.

Magnesium $\left(\mathrm{Mg}^{+2}\right)$ is a water-soluble alkaline earth metal with a single oxidation state. The sources of magnesium in natural water are the weathering of rocks and minerals containing magnesium like: dolomite, magnesite in sedimentary rocks [15]. It occurs as an adsorbed ion on clays in clay minerals. [16]. The main source of magnesium $\left(\mathrm{Mg}^{+2}\right)$ in the studied area is the dissolution of dolomite limestone of Dibdibba Formation. Magnesium $\left(\mathrm{Mg}^{+2}\right)$ concentrations in groundwater samples range from (127-372.3) ppm.

The main source of sodium in groundwater is the effect of evaporate rocks, alkalinity feldspar, and ionic exchange of clay minerals during the erosion process. [8], where the salts and sodium compounds have high solubility in water. Sodium has many salts such as, sodium carbonate, which forms generate in salty lands, sodium bicarbonate, which is the least soluble salts, and sodium sulfate, which is soluble and able to be deposited under affected temperature in cold climates [15]. The main source of sodium $\left(\mathrm{Na}^{+}\right)$in the studied area is evaporates deposits. The concentration of sodium $\left(\mathrm{Na}^{+}\right)$ in the groundwater samples ranges between (411-1384.8) ppm.

Potassium $\left(\mathrm{K}^{+}\right)$is slightly more common in sedimentary rocks than sodium, but it is less abundant in all igneous rocks. The scarcity of potassium in groundwater is attributable to two factors: one is the resistance to weathering of minerals of potassium and another to weathering of potassium in clay minerals [17]. The potassium $\left(\mathrm{K}^{+}\right)$concentration in the groundwater samples ranges between $(11-116)$ ppm.

Total Hardness (T.H.) is a measurement of water's ability to precipitate soap. It is similar to alkalinity, which would be typically described as an equivalent concentration of $\mathrm{CaCO}_{3}{ }^{-}$Hardness, on the other hand, is a property of cations $\left(\mathrm{Ca}^{+2}\right.$ and $\left.\mathrm{Mg}^{+2}\right)$, whereas alkalinity is a property of anions $\left(\mathrm{HCO}_{3}^{-}\right.$and $\mathrm{CO}_{3}^{-2}$ ).The total hardness is the sum of concentrations of calcium and magnesium ions in $\mathrm{mg} / \mathrm{L}$. and is usually expressed as the equivalent of $\mathrm{CaCO}_{3}[18]$ : 
Total hardness $\left(\right.$ as $\left.\mathrm{CaCO}_{3}\right)=2.497\left[\mathrm{Ca}^{+2}\right]+4.118\left[\mathrm{Mg}^{+2}\right]$.

Where: $\mathrm{TH}, \mathrm{Ca}^{+2}, \mathrm{Mg}^{+2}$ are all measured in $\mathrm{ppm}(\mathrm{mg} / \mathrm{L})$. Calcium $\mathrm{Ca}^{+2}$, magnesium $\mathrm{Mg}^{+2}$, and $\mathrm{HCO}_{3}^{-}$ often account for the majority of total dissolved solids (TDS), so hardness can be used as an indicator proportionate to the total dissolved solids present. Hardness is a significant criterion to determining water drinking usability, domestic and many industrial uses [17]. The (T.H.) in the groundwater samples ranges between (973-2548.3) ppm.

The chlorine $\left(\mathrm{Cl}^{-}\right)$is the most abundant of the halogens and is a minor component of earth crusts, but in most natural water it is considered as a major dissolved component. The presence of high chloride ion concentrations in water is caused by the difficulty of adsorption on clay mineral surfaces and the ease of solubility [19]. The main source of chloride in groundwater samples due to clay and gypsum units within the Dibdibba Formation. The chlorine $\left(\mathrm{Cl}^{-}\right)$concentration in the groundwater samples ranges between (540-2209) ppm.

The main source of sulfate in groundwater is sulfate mineral solutions found in sedimentary rocks, as well as oxidation of barite minerals, [16]. The main source of sulfate $\left(\mathrm{SO}_{4}{ }^{-2}\right)$ in the study area is solutions of sulfate minerals that exist in evaporate rocks such as gypsum. The concentration of sulfate $\mathrm{SO}_{4}{ }^{-2}$ in the groundwater samples ranges between (990-3260) $\mathrm{ppm}$.

Bicarbonate $\left(\mathrm{HCO}_{3}{ }^{-}\right)$and carbonate $\left(\mathrm{CO}_{3}^{-2}\right)$ are the source of water alkalinity. Bicarbonate ions in groundwater derived from the carbon dioxide $\left(\mathrm{CO}_{2}\right)$ in the atmosphere, carbon dioxide in the soil and the dissolution of carbonate rocks such as limestone and dolomite. The concentration of bicarbonate $\left(\mathrm{HCO}_{3}{ }^{-}\right)$in the groundwater samples ranges between (310-1342) ppm.

Nitrate is highly soluble in water and weak retention by soil. Nitrite $\left(\mathrm{NO}_{2}{ }^{-}\right)$can be transformed into nitrate $\left(\mathrm{NO}_{3}^{-}\right)$when brought the groundwater to the surface or exposed to air in wells. Nitrate originates mainly from agricultural activities due to the use of fertilizers. The sources of organic nitrates related to human sewage and livestock manure, especially from feedlots [15]. The concentration of nitrate $\left(\mathrm{NO}_{3}{ }^{-}\right)$in the groundwater samples ranges between $(0.2-11) \mathrm{ppm}$.

\section{Statistical analyses}

The studied groundwater samples were evaluated statistically by using multivariate analyses (Correlation coefficient, Cluster analyses, and Factor analyses). TDS, EC, pH, Cations, and Anions for 33 groundwater samples were used after eliminated the scale difference among these parameters by the standardization of each variable firstly according to [20].

The correlation coefficient analyses show significant correlations between the groundwater variables Table-4. High positive correlation value between TDS, EC with $\mathrm{Na}^{+}, \mathrm{Ca}^{+2}, \mathrm{Mg}^{+2}$, and $\mathrm{Cl}^{-}$in addition to the significant correlation between $\mathrm{SO}_{4}^{-2}$ and $\mathrm{HCO}_{3}^{-}$, whereas there is medium positive correlation between $\mathrm{EC}$, TDS and $\mathrm{HCO}_{3}^{-}$. $\mathrm{NO}_{3}{ }^{-2}$ concentration has a weak correlation with $\mathrm{HCO}_{3}^{-}, \mathrm{Cl}^{-}, \mathrm{Mg}^{+2}$ and $\mathrm{Na}^{+}$parameters.

Table 4- Correlation coefficient matrix of the studied groundwater quality in the study area

\begin{tabular}{|c|c|c|c|c|c|c|c|c|c|c|c|c|}
\hline & & & & & Correla & tion $\mathrm{M}$ & trix $^{a}$ & & & & & \\
\hline & & pH & Ec & TDS & $\mathbf{K}^{-}$ & $\mathrm{Na}^{+}$ & $\mathbf{M g}^{+2}$ & $\mathbf{C a}^{+2}$ & $\mathrm{Cl}^{-}$ & $\mathrm{SO}_{4}{ }^{-2}$ & $\mathrm{HCO}_{3}$ & $\mathrm{NO}_{3}{ }^{-2}$ \\
\hline & $\mathrm{Ph}$ & 1.000 & & & & & & & & & & \\
\hline & Ec & $-.203-$ & 1.000 & & & & & & & & & \\
\hline & TDS & $-.196-$ & .996 & 1.000 & & & & & & & & \\
\hline & $\mathbf{K}^{-}$ & .188 & $-.202-$ & $-.163-$ & 1.000 & & & & & & & \\
\hline Pearson & $\mathrm{Na}^{+}$ & $-.181-$ & .930 & .932 & $-.120-$ & 1.000 & & & & & & \\
\hline Correlatio & $\mathbf{M g}^{+2}$ & $-.159-$ & .914 & .920 & $-.064-$ & .981 & 1.000 & & & & & \\
\hline $\mathrm{n}$ & $\mathbf{C a}^{+2}$ & $-.236-$ & .921 & .924 & $-.148-$ & .961 & .962 & 1.000 & & & & \\
\hline & $\mathrm{Cl}^{-}$ & $-.176-$ & .915 & .921 & $-.049-$ & .980 & .975 & .979 & 1.000 & & & \\
\hline & $\mathrm{SO}_{4}{ }^{-2}$ & $-.238-$ & .866 & .878 & $-.102-$ & .923 & .911 & .909 & .901 & 1.000 & & \\
\hline & $\mathrm{HCO}_{3}$ & $-.218-$ & .777 & .789 & .087 & .917 & .927 & .909 & .935 & .840 & 1.000 & \\
\hline & $\mathrm{NO}_{3}^{-2}$ & $-.027-$ & .526 & .553 & .250 & .616 & .652 & .586 & .658 & .520 & .713 & 1.000 \\
\hline
\end{tabular}

The cluster analysis technique is used to assume the assemblages of groundwater samples according to their characteristics into many groups [21]. Figure-6 shows the Dendrogram of the hierarchical cluster analyses of 33 groundwater samples for the same chemical and physical 
parameters. Two significant clusters I and II are obtained, the groundwater samples 11 and 12 have different in their properties from the other samples. The most important factors that responsible for playing the most important role in classifying the present water samples are TDS and Ec that reflect the high salinity pollution in the present study area.

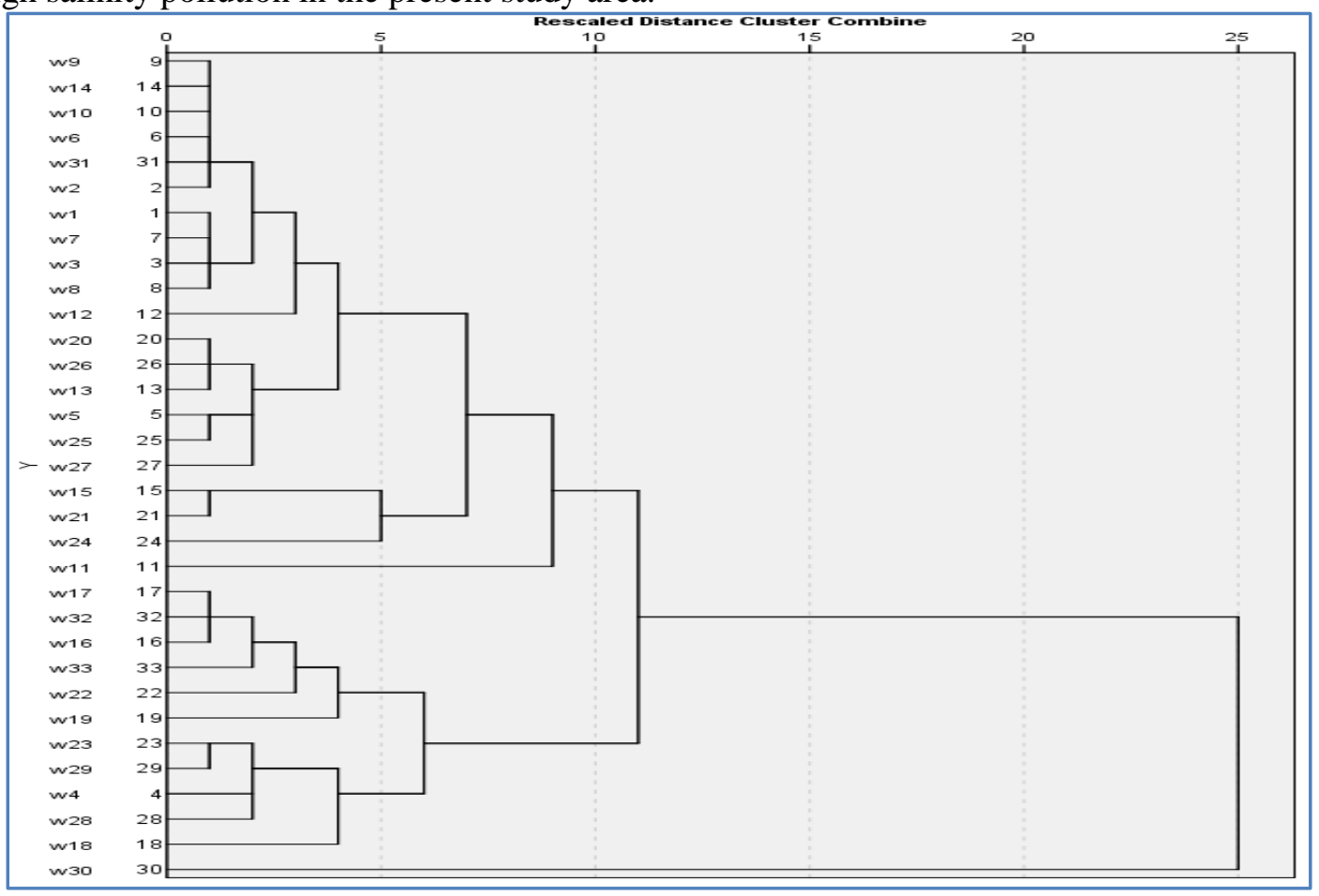

Figure 6- Dendrogram of the studied groundwater samples.

Factor analysis technique is applied to many observed variables to find the reducing factors (subsets of variables) depend on the correlation matrix of observed variables contain the weighted average of the original variables. The principle component analysis method was used to evaluate principle component, factors, eigenvectors, or loading that represents the score of the forecasting component [22]. The subsets of variables (sub-clusters) in one cluster that depend on the similarity of the observed chemical and physical parameters refer to the strong correlation between them.

Based on the eigenvalues $>1$, two Factors explained about $71.855 \%$ and $12.214 \%$ of the percent of the total variances of the groundwater samples (Table -5). The factor I show that $\mathrm{Cl}^{-}, \mathrm{Mg}^{+2}, \mathrm{Na}^{+}$and $\mathrm{Ca}^{+2}$ with highest weighted variables average as well as $\mathrm{HCO}_{3}{ }^{-}$, TDS, $\mathrm{Ec}$, and $\mathrm{SO}_{4}^{-2}$. Nitrate $\mathrm{NO}_{3}{ }^{-2}$ has the lowest weight variable among the other variables, whereas, Factor II shows a high weight average of $\mathrm{K}^{+}$concentration only (Table-6).

The correlations and Factors analyses suggest a common source of $\mathrm{Mg}^{+2}, \mathrm{Ca}^{+2}, \mathrm{Cl}^{-}$, and $\mathrm{K}^{+}$that related to the dissolution of sulfate salts and evaporates minerals, in addition to high drainage from agricultural lands, farms, besides the chemical construction industries [23]. The excessive used of softeners, the powder of detergents caused increasing in $\mathrm{Mg}^{+2}$ and $\mathrm{Na}^{+}$because these form insoluble salts with soap [24].

Table 5- The extracted total variance percent of the studied groundwater quality.

\begin{tabular}{|c|c|c|c|c|c|c|c|c|c|}
\hline & & & Total & Varia & Ice Expla & ined & & & \\
\hline Compone & & tial Eigen & jalues & Extrac & $\begin{array}{r}\text { tion Sums } \\
\text { Loadin }\end{array}$ & $\begin{array}{l}\text { of Squared } \\
\text { gs }\end{array}$ & Rotat & $\begin{array}{l}\text { Ion Sums } \\
\text { Loadin }\end{array}$ & $\begin{array}{l}\text { of Squared } \\
\operatorname{lgs}\end{array}$ \\
\hline nt & Total & $\begin{array}{c}\% \text { of } \\
\text { Variance }\end{array}$ & $\begin{array}{c}\text { Cumulative } \\
\%\end{array}$ & Total & $\begin{array}{c}\% \text { of } \\
\text { Variance }\end{array}$ & $\begin{array}{c}\text { Cumulative } \\
\%\end{array}$ & Total & $\begin{array}{c}\% \text { of } \\
\text { Variance }\end{array}$ & $\begin{array}{c}\text { Cumulative } \\
\%\end{array}$ \\
\hline 1 & 7.904 & 71.855 & 71.855 & 7.904 & 71.855 & 71.855 & 7.823 & 71.121 & 71.121 \\
\hline 2 & 1.344 & 12.214 & 84.069 & 1.344 & 12.214 & 84.069 & 1.424 & 12.948 & 84.069 \\
\hline 3 & .866 & 7.875 & 91.944 & & & & & & \\
\hline 4 & .428 & 3.889 & 95.832 & & & & & & \\
\hline
\end{tabular}




\begin{tabular}{|c|c|c|c|c|c|c|c|c|c|}
\hline 5 & .236 & 2.147 & 97.979 & & & & & & \\
\hline 6 & .124 & 1.125 & 99.104 & & & & & & \\
\hline 7 & .043 & .387 & 99.490 & & & & & & \\
\hline 8 & .028 & .258 & 99.748 & & & & & & \\
\hline 9 & .020 & .185 & 99.933 & & & & & & \\
\hline 10 & .005 & .043 & 99.976 & & & & & & \\
\hline 11 & .003 & .024 & 100.000 & & & & & & \\
\hline \multicolumn{10}{|c|}{ Extraction Method: Principal Component Analysis. } \\
\hline
\end{tabular}

Table 6- The Factor loading of the studied groundwater quality.

\begin{tabular}{|c|c|c|}
\hline \multirow{2}{*}{ variable } & \multicolumn{2}{|c|}{ Component } \\
\cline { 2 - 3 } & Factor I & Factor II \\
\hline $\mathrm{pH}$ & $-.228-$ & .528 \\
\hline $\mathrm{Ec}$ & $\mathbf{. 9 3}$ & $-.143-$ \\
\hline $\mathrm{TDS}$ & $\mathbf{. 9 5 0}$ & $-.104-$ \\
\hline $\mathrm{K}^{-}$ & $-.088-$ & $\mathbf{8 6 6}$ \\
\hline $\mathrm{Na}^{+}$ & $\mathbf{. 9 8}$ & $-.019-$ \\
\hline $\mathrm{Mg}^{+2}$ & $\mathbf{. 8 4}$ & .044 \\
\hline $\mathrm{Ca}^{+2}$ & $\mathbf{. 9 7 9}$ & $-.071-$ \\
\hline $\mathrm{Cl}^{-}$ & $\mathbf{. 8 7}$ & .049 \\
\hline $\mathrm{SO}_{4}^{-2}$ & $\mathbf{. 9 3 1}$ & $-.070-$ \\
\hline $\mathrm{HCO}_{3}^{-}$ & $\mathbf{. 9 2 9}$ & .178 \\
\hline $\mathrm{NO}_{3}^{-2}$ & $\mathbf{. 6 7 0}$ & .488 \\
\hline & Extraction Method: Principal Component Analysis. \\
\hline
\end{tabular}

\section{Ground Water Uses:}

Groundwater is used for several purposes in the area region depending on the type of water and the anions and cations content, which varies from one type to the other. As a result, water must be evaluated by local and international standards to determine its suitability for various uses.

\section{Water Uses for Drinking Purposes:}

Developed multi-standard specifications for potable water and compared the concentrations of ions and total soluble salinity samples of groundwater in the study area and show that groundwater in the study area is unsafe to drink, according to the [25], [26](Table7).

Table 7-Comparing the parameters for water samples with the standards of drinking water (IQS, 2009) [25] and (WHO, 2011) [26].

\begin{tabular}{|c|c|c|c|c|}
\hline Parameters & IQS 2009 & $\begin{array}{c}\text { WHO } \\
2011\end{array}$ & $\begin{array}{c}\text { studied wells } \\
\text { (Mean) }\end{array}$ & Suitability \\
\hline $\mathrm{pH}$ & $6.5-8.5$ & $6.5-8.5$ & 7.27 & Suitable \\
\hline $\mathrm{EC}(\mu \mathrm{S} / \mathrm{cm})$ & 1500 & 1530 & 7679.03 & All samples is not suitable \\
\hline $\mathrm{TDS}(\mathrm{ppm})$ & 1000 & 1000 & 5479.36 & All samples is not suitable \\
\hline $\mathrm{Ca}^{+2}(\mathrm{ppm})$ & 150 & 75 & 418.11 & All samples is not suitable \\
\hline $\mathrm{Mg}^{+2}(\mathrm{ppm})$ & 100 & 125 & 196.78 & All samples is not suitable \\
\hline $\mathrm{Na}^{+}(\mathrm{ppm})$ & 200 & 200 & 715.49 & All samples is not suitable \\
\hline $\mathrm{K}^{+}(\mathrm{ppm})$ & - & 12 & 55.07 & $\begin{array}{c}\text { Samples(10,13) is suitable and } \\
\text { other is not suitable }\end{array}$ \\
\hline $\mathrm{CL}^{-}(\mathrm{ppm})$ & 350 & 250 & 939.95 & All samples is not suitable \\
\hline $\mathrm{SO}_{4}^{-2}(\mathrm{ppm})$ & 400 & 250 & 1608.81 & All samples is not suitable \\
\hline $\mathrm{NO}_{3}^{-}(\mathrm{ppm})$ & 50 & 50 & 3.83 & All samples is suitable \\
\hline
\end{tabular}

\section{Water Uses for Livestock:}

Used the proposed specifications [12]. That rely on some of the positive and negative ions and dissolved salts and total hardness, and when the waters of the study area compared with these specifications are found to be fit for animal consumption. 


\section{Water Uses for Industrial Purposes:}

[15] Notify some of the standard specifications of the water used in various industries and water when compared to the study area shows that most of this water is not suitable to all industries.

Suitability of Groundwater for Construction Purpose:

The reasonableness of groundwater in the study area is assessed for structural purposes using the arrangement proposed by [27], the results show that most groundwater wells in the study region were unsuitable due to increased concentration of sulfate and bicarbonates.

\section{Groundwater Uses for Agricultural Purposes:}

The appropriateness of water for farming relies upon the sum and sort of salts present in the water and their impacts on yield development and improvement. Furthermore, crop growth and development are dependent on plant response to various environmental conditions, plant quality, soil structure characteristics, irrigation pattern, plant susceptibility to absolute disintegrated solids, and electrical conductivity in water, all of which are dependent on nature of plants [16].Comparing with [16] the samples of the study area depending on Ec value, water isnot suitable for some sorts of yields.

\section{Groundwater Suitability for Irrigation Purposes}

Water's suitability for irrigation is determined by ion concentrations in the water, with the saline content expressed by electrical conductivity salinity [27]. The irrigation water is classified by [28] into four categories based on the EC values, as shown in table (8). According to groundwater samples classification for the study area, the $\mathrm{C} 4$ water type represents all wells, which are generally unacceptable for irrigation, except for very salt-tolerant plants, excellent drainage, frequent leaching, and intensive management Table (8).

Table 8- Classification of irrigation water based on (EC) values [28].

\begin{tabular}{|c|c|c|}
\hline level & $\mathrm{EC}(\boldsymbol{\mu S} / \mathbf{c m})$ & Hazard and Limitations \\
\hline $\mathrm{C} 1$ & $<250$ & $\begin{array}{c}\text { Low hazard; no detrimental effects on plants, and no soil buildup } \\
\text { expected. }\end{array}$ \\
\hline $\mathrm{C} 2$ & $250-750$ & $\begin{array}{l}\text { Sensitive plants may show stress; moderate leaching prevents salt } \\
\text { accumulation in soil }\end{array}$ \\
\hline $\mathrm{C} 3$ & $750-2250$ & $\begin{array}{l}\text { Salinity will adversely affect most plants; requires selection of salt } \\
\text { tolerant plants, careful irrigation, good drainage, and leaching }\end{array}$ \\
\hline $\mathrm{C} 4$ & $>2250$ & $\begin{array}{c}\text { Generally unacceptable for irrigation, except for very salt tolerant } \\
\text { plants, excellent drainage, frequent leaching, and intensive } \\
\text { management }\end{array}$ \\
\hline
\end{tabular}

\section{Residual sodium bicarbonate (RSBC)}

The bicarbonate concentration increasing will be caused by increased concentrations of calcium and magnesium in addition, to an increase in sodium concentration [29], having a negative impact on the soil. According to [30] the RSBC was divided into three categories: acceptable when RSBC $<5$ meq/L, marginal if RSBC ranged between 5-10 meq/L, and unsatisfactory with RSBC $<10$ meq, the $\mathrm{RSBC}$ is calculated by using the equation in epm units for all the ion concentrations:

$$
\mathrm{RSBC}=\left(\mathrm{HCO}_{3}^{-}-\mathrm{Ca}^{+2}\right)
$$

The RSBC result of the present samples was ranged between -18.5 to $-3.0 \mathrm{meq} / \mathrm{L}$ with an average of $-10.7 \mathrm{meq} / \mathrm{L}$, The majority of sample RSBC values are considered satisfactory $(<5 \mathrm{meq} / \mathrm{L})$ (Table 2 and 3). The majority of the samples in the study area are suitable for irrigation.

\section{Magnesium Ratio (MR)}

The Magnesium ratio (MR) is the excess of magnesium concentration over $\mathrm{Ca}^{+2}$ and $\mathrm{Mg}^{2+}$, and it was calculated using the equation below for [31], with the ionic concentrations in epm units

$$
\mathrm{MR}=\left[\mathrm{Mg}^{+2} /\left(\mathrm{Mg}^{+2}+\mathrm{Ca}^{+2}\right)\right]^{* 100}
$$

The soil becomes very alkaline when the values of MR is more than $50 \%$ and if MR less than $50 \%$ was suitable for irrigation purpose [29], the present groundwater samples contain magnesium ratio ranged between ( $38.6-47.9)$ meq/L with an average of $43.6 \mathrm{meq} / \mathrm{L}$ confirms suitable water for irrigation purposes, (Table 2 and 3 ) 


\section{Permeability index (PI)}

Soil permeability is affected by long-term irrigation purposes which caused sodium, calcium, a magnesium and bicarbonate presence in soil. The permeability index is developed by [32] calculated by the following equation when the ion concentrations used in meq/L units:

$$
\left.\mathrm{PI}=\left[\mathrm{Na}+\left(\mathrm{HCO}_{3}^{-}\right)^{0.5}\right)\right]^{* 100} /\left(\mathrm{Na}^{+}+\mathrm{Ca}^{+2}+\mathrm{Mg}^{+2}\right)
$$

According to the permeability index (PI), groundwater was divided into three classes. Class I is as excellent for irrigation with PI is greater than $75 \%$; class II is good for irrigation when the PI is between 25, and 75\%; and class III is inappropriate for irrigation when the PI is less than 25\%. [33]. The present groundwater samples results are ranges between $(0.004-0.005) \mathrm{meq} / \mathrm{L}$ with an average $(0.0001) \mathrm{meq} / \mathrm{L}$, were considered as unsuitable for irrigation (Table 2 and 3 )

\section{Conclusion:}

The hydrochemical characteristics of thirty-three groundwater samples were studied and the following conclusions were reached:

- The water of the study area is colorless, odorless, while it has a salty taste in some of the groundwater samples due to the increase in TDS values, and has close temperatures dominated by sulfate ions, sodium. Hydrochemical analysis of groundwater proved that it has a very hard type according to Todd 2007 classification as the total hardness values ranged between (973-2548.3) ppm. As for the total dissolved solids, their value ranged between (2640-10415) ppm and that the large proportion of groundwater samples in the field area are sodium sulfate $\mathrm{Na}_{2} \mathrm{SO}_{4}$ type.

-The multivariate analyses of the present studied samples indicated high drainage from agricultural lands, farms, besides the chemical construction industries, in addition to the excessive use of softeners and the powder of detergents that caused increasing in $\mathrm{Cl}^{-}, \mathrm{Mg}^{+2}, \mathrm{Na}^{+}$and $\mathrm{Ca}^{+2}$ with the highest weighted variables average as well as $\mathrm{HCO}_{3}^{-}$, TDS, Ec, and $\mathrm{SO}_{4}^{-2}$.

-Through studying the groundwater suitability for different uses validity that water unfits to drink and for industrial uses and the purposes of building and construction, as well as for agricultural purposes, while is valid for animal consumption.

\section{References}

1. Haddad, R. H.and Hawa, A. J. 1979. "Hydrogeology of the Safwan-Zuber area, south of Iraq. Tech. Bull, (132).," vol. 132.

2. A. Al- Kubaise. 1996. The environmental reality of Saddam River., Unpubl.Ph.D. thesis, Univ. of Baghdad, College of Science, p. 142.

3. N. M. S. Numan. 1997. "A plate Tectonic Scenario for the PhanerozoicSuccession in Iraq.," Iraqi Geological Journal, 30( 2).

4. Buday, T. and Jassim, S. Z. 1987. " The Regional Geology of Iraq, Tectonism, Magmatism, and Metamorphism.," Publication of GEOSURV, Baghdad, 2: 352p., 1987.

5. Abdulameer $\mathrm{M}, \mathrm{H}$ and Al-mallah I.A. 2018. "Evaluation of groundwater quality and the hydrogeochemical processes of shallow Dibdibba aquifer in Basra Governorate, southern Iraq," Journal of Basrah Researches ((Sciences)), 44(1).

6. F. Abdulhussein. 2018. " Hydrochemical Assessment of Groundwater of Dibdibba Aquifer in AlZuber Area, Basra, South of Iraq and its Suitability for Irrigation Purposes.," Iraqi Journal of Science, 59(1A): 135-143.

7. Towfik1, S.M. and Hammadi, A. J. 2020. " Water Quality of Groundwater in Selected Wells in Zuber Area, Basra City.," Iraqi Journal of Science, 61(6): 1370-1382.

8. Appelo, C.A.J. and Postma, D. 1999. Geochemistry.Groundwater andPollution.Rotterdam, 536p..

9. W. H. O. (WHO). 2008. Guidelines for drinking waterquality., 3rd ed., vol. Vol.1, Geneva, 516p

10. C. Boyd. 2000. Water Quality, an Introduction., USA: Kluwer Acad. Publisher, p. 330.

11. W. Walton. 1970. Groundwater resources Evaluation., Tokyo: McGraw-Hill Kogakusha, p. 464.

12. M. E. Altovisiki. 1962. Hand book of hydrogeology., USSR: Geogoelitzet, Moscow, p. 614.

13. J. I. Drever. 1997. The geochemistry of natural water, surface and groundwater environments., 3rd ed., USA: Prentice Hall, p. 436. 
14. M. Detay. 1997. Water Wells implementation, maintenance and restoration., London: John Wiley and Sons, p. 379.

15. J. Hem. 1991. Study and interpretation of the chemical characteristics ofnatural water, USA: U.S. Geological Survey, Water Supply, 1991, p. 263.

16. D. Todd. 2007. Groundwater hydrology., 2nd end ed., USA: John Wiley \& Sons., p. 535P.

17. K. R. Karanth. 2008. Groundwater assessment development and management., New Delhi: Tata McGraw-Hill Offices, p. 720.

18. G. Faure. 1998. Principles and application of geochemistry, (2nd ed. ed., USA: Prentic Hall, Inc., p. 600.

19. G. Faure. 1998. Principles and application of geochemistry, (2nd ed. ed., USA: Prentic Hall, Inc., p. 600 .

20. Almallah, I, Alsuhail, Q, and Albadran, A. 2016. ".Mineralogical and Geochemical analyses of the sediments surrounding the Main Drain raea, Middle of Iraq.," Iraqi Journal of Science., 57 (3B): 2025-2042.

21. Nnorom, I. C., Ewuzie, U., and Eze, S. O. 2019. "Multivariate statistical approach and water quality assessment of natural springs and other drinking water sources in Southeastern Nigeria.," Heliyon, 5(1): 1123.

22. Fayydh A, ZaidanT, and Al- Heety E. 2020. " Evaluation of groundwater quality in Al waffa and Kubaysa areas using multivariate atatisticalanalyses , Al -Anbar western Iraq.," Iraqi Geological Journal, 53(2D): 107-127.

23. R. Ibrahim. 2009. Hydrochemistry of shallow groundwater in Western part of Karbala city, Baghdad: Unpubl.M.Sc.thesis in geology, Univ. of Baghdad.

24. G. (. f. C. D. W. Quality). 2007. "Chemical analysis interpretation of domestic farm water supplies.," [Online]. Available: -www.agric.gov.ab.ca/ app84/ rwqit.1-August-2007.. [Accessed August 2007].

25. I. Standard. 2009. "Iraqi standard of drinking water," .

26. W. H. O. (WHO). 2011."Guideline for drinking water quality," World Health Organization, Geneva.

27. Ayers, R.S.andWestcot .W. 1985. " water quality for agriculture, FAO,," FAO of theUN, Romme.

28. A. Turgeon. 2000. "Irrigation Water Quality," College of Agricultural sciences The Pennsylvania StateUniversity, USA.

29. J. W. Van Hoorn. 1970. Quality of irrigation water, limits of use and prediction of long term effects.

30. Gupta, S. K., \& Gupta, I. C. 1987. Management of saline soils and waters.Management of saline soils and waters.

31. K. V. Paliwal. 1972. "Irrigation with saline water.," Indian Agriculture Research Institute, New Delhi.

32. L. D. Doneen. 1962. " The influence of crop and soil on percolating water.," in Biennial conference on Groundwater recharge )., In Proc.

33. H. B. Ghalib. 2017. " Groundwater chemistry evaluation for drinking and irrigation utilitiesin east Wasit province, Central Iraq.," Applied Water Science,, 7(7): 3447-3467. 